\title{
Thought to teaching methodology in the course of Tax Law in the major of accounting
}

\author{
Jie Li \\ Wuchang University of Technology, Wuhan, 430223, China
}

Keywords: teaching method; evaluation system; heuristic education; contrastive teaching

\begin{abstract}
: legal system of state tax revenue is being reformed in order to adapt national economic transition mode. As college education reform increasingly deepens, social demand also requires colleges cultivating academic talents to applied talents. Tax Law as one of core courses of accounting major is also faced with a reform in order to adapt era development and educational reform needs. This paper starts with explanation of the status and features of Tax Law, analyzes teaching status of this course and puts forward some exploratory ideas about Tax Law reform in combination of social and enterprise demand for talents.
\end{abstract}

\section{Status and features of Tax Law in accounting major teaching}

\section{Status of Tax Law}

Tax law is a generic term of legal norms used to adjust relationship of tax collection and payment rights and obligations between the state and tax payers. The sources of tax revenue mainly include enterprises, individual business and individuals. Tax revenue has great effects on business activities and benefits of the above groups and individuals and is paid high attention to. So, society and enterprises require accounting personnel at different levels and in different positions owning the following professional abilities: master necessary knowledge of tax law, correctly calculate tax amount, carry out accounting treatment and declaration and lighten enterprise and individual tax burden through legal means.

Seeing from professional growth route of accountancy, the knowledge of tax law is key knowledge and necessary examination subject regardless of the examination of accountant certificate and job title of accountants or the examination of certified public accountants and certified tax agents. Therefore, Chinese colleges set courses related to tax law for finance and economics major. Tax Law is an essential part in accounting major course system.

2. Features of Tax Law

Compared with other courses, Tax Law has the following three features:

(1) Policy and timeliness

Although china has had thorough tax law system, there are only two income tax laws, law of vehicle and vessel tax and law of collection and management passed by the National People's Congress and its the National People's Congress. The remaining laws exist in the form of provisional regulations or enforcement regulations. This is mainly because China is in economic transition period. As macroeconomic policy changes continuously, tax law will be correspondingly adjusted and perfected. So, teaching contents of Tax law must keep up with national macro-policy and adjustments. This reflects policy and timeliness.

(2) Relevance

Tax Law and Accounting are closely related. For example, material purchase or product sales existing in Accounting will involve added-value tax, consumption tax, extra charges of education funds, educational expense and stamp tax etc. Disposal of fixed assets and intangible assets in Accounting will involve business tax. Income tax expense in financial profit statement will correlate with corporate income tax. Besides, tax categories in tax law system also have close relationship. For example, tobacco and wine sale will involve added-value tax, consumption tax, urban construction tax and extra charges of education funds. During calculating corporate income tax, six taxes and one expense in business tax and surcharges need to be ducted. These show relevance of Tax law. 


\section{For (3) Pragmatism}

For common citizens, they need to pay tax according to laws. As a student majoring in accounting, he must master relevant theoretical knowledge, be able to correctly calculate the amount of tax, complete tax declaration and relevant accounting treatment, know China tax collection and management procedure and lay a solid foundation for future relevant jobs. This requires students carefully learning theoretical knowledge, often participating in tax calculation, tax-related business handing and declaration, and simulating revenue administrators so as to improve their cognition of practice, finish work and solve problems.

\section{Teaching status of Tax Law of accounting major}

Although colleges set courses related to tax law, teaching effects and satisfaction degree of knowledge mastery have been on the decrease in recent years. The problems existing in Tax Law teaching mainly include the following:

1. Teachers' knowledge structure is imperfect

Perfect teaching team is a key factor to ensure teaching quality and drive teaching reform. Update of follow-up teaching materials, reform of teaching methods and means, reconstruction of evaluation system and practical training environment construction cannot be separated from excellent teaching team. At present, in college TX Law teaching, some teachers come from law major; some come from finance and economics major. The teachers majoring in law generally have no accounting knowledge and have natural weakness. Moreover, the teachers majoring in accounting major generally have strong theoretical knowledge and weak practical ability. Even if some schools employ tax personnel in enterprises to teach Tax Law, but the lack of teaching experience also greatly affects teaching effects.

2. Knowledge update in teaching materials lags behind current tax reform trend

In order to adapt national economic model transition, adjustment and modification of tax law policies and contends gradually become normal, but there is certain period from teaching material preparation to publishing. Thus, teaching materials inevitably lag behind reform of national tax revenue law. Tax law principles explicitly stress new laws are superior to old laws. Once new laws are issued, old laws lose legal force. In daily teaching, the students concerning national tax reform will put forward the consistence between teaching material contents and tax reform contents, when teaching material contents must be changed. This will give rise to many troubles for teaching. If teachers completely teach according to their knowledge mastered without considering teaching materials, students and teachers will lose a platform to communicate through teaching materials. Hysteresis of teaching material contents is a bottleneck restricting Tax Law teaching.

3. Teaching method and means are single

Currently, class hours of Tax Law is low, generally 54 or 72 class hours. Teachers generally adopt traditional cramming method in order to complete teaching tasks. There is no time for students to participate in analysis. For articles students are difficult to undressed, numerous tax preference or tax formulas, students are required to memorize mechanically. Thus, students' class participation degree is low, with small interest, and classroom climate is poor. In addition, there are many students in a class and many classes. Situations of each student are different. It is hard for teachers' traditional teaching mode to improve teaching effects.

4. Evaluation system is not scientific

At present, Tax Law evaluation is dominated on final written examination and supplemented by ordinary performance. As mentioned above, there are many students in a class and many classes. It is difficult to objectively evaluate ordinary performance of each student. Teachers most give scores according to students' class ordinary performance. The core of the final score is the final examination. The test paper pays attention to theoretical knowledge and neglects practice. Students often prepare examinations through making effort at the last moment. In this way, students fail to analyze and think theoretical knowledge, and neglect learning and mastery of practical knowledge. Thus, it is hard for them to improve comprehensive quality.

5. Practice learning environment is imperfect 
Now that Tax Law has strong practice, practical teaching link is indispensable. Besides, supporting practice base is also very important. Current practical teaching link is completed in a laboratory through software. But, current software has no strong supporting nature or is out-dated. It is hard to improve students' ability to cognize practical knowledge through simulation. For practice base, there are many students majoring in accounting. General enterprises or firms cannot accept so many interns or they are unwilling to reveal their financial information. Thus, students cannot practice geared to their major. Finally, their practice becomes practice at the grassroots. In such case, students' theoretical knowledge is disconnected with their practical knowledge and they lack cognition of tax revenue practice.

\section{Current social demand for tax revenue talents}

The Ministry of Finance explicitly points out in medium-and-long-term Talent Development Planning 2010-2020 of Accounting Profession, financial departments at each level should establish industry-study-research strategic alliances based on employers and oriented to market, and generalize accounting talent cultivation mode based on college teaching and supplemented by company practice; all sectors of society should perform social responsibility, set up accounting talent cultivation platform and jointly drive accounting talent cultivation.

The author participated in revising National Accounting Occupational Classification in 2010 and surveyed financial senior executives and accounting personnel of multiple enterprises. Currently, enterprises and society need applied talents of tax revenue. In other words, they need the talents who can apply theoretical knowledge and skills in practical work. Therefore, compound talents with sufficient theoretical knowledge and strong practices ability are the cultivation objective. Take tax accounting position for example. Relevant personnel need to grasp the latest finance and taxation information, operate tax-related business of tax payers, prepare tax return, declare on time, pay tax payable in time and account related economic business.

IV. Tax Law reform thinking

1. To carry out teaching team building

Starting from the final demand of courses serving society, colleges should employ some personnel who own enterprise tax revenue experience. However, seeing from college income level, it is very difficult to fulfill this idea. So, colleges have to build teaching team according to existing conditions. Colleges can jointly formulate study plans together with course teachers, actively contact enterprises through competent education department, government, financial department and tax department to provide practice platforms and opportunities for teachers. Relevant government departments should provide certain preferential tax policy for the enterprises offering the opportunities. Meanwhile, colleges and enterprises can create practice opportunities for more students and teachers to demonstrate the sense of social responsibility. Furthermore, colleges can set up college-run enterprises and let teachers feel the practice.

2. To combine current tax reform form and form suitable college-based lecture notes

Under the condition where teaching materials cannot completely keep pace with tax reform policy, a college can organize its teachers and other teachers from other colleges to prepare suitable college-based lecture notes in combination of latest tax reform knowledge, which can connect with national policy in time, ensure normal use of other teaching material content and provide good reference for follow-up college-based lecture notes becoming official teaching materials.

3. To change existing teaching mode and means, and motivate students' participation

Tax Law teaching should be based on inheriting traditional teaching methods, change cramming teaching pattern, adopt heuristic teaching method, situational teaching method, task-driven method, case teaching method and comparative teaching method and better apply multi-media and other modern teaching means.

Heuristic teaching method mostly adopts pithy formula memory. In daily study, many students feel there are too many knowledge points of tax law in need of remembering. Associative summary memory can gain a good effect. Situational teaching method can help students place themselves in real situations through invoice application, tax return, online tax-declaration and simulation of prize 
winning game. Task-driven method means teachers assign taxpayer type confirmation, taxation scope, tax amount computation and declaration tasks to students before class through referring to a tax-related enterprise case. In this way, students with tasks can learn knowledge with teachers. In case teaching method, hot taxation cases are used for explanation and free discussion, such as the case of writing false value added tax invoices. Teachers arrange students preview before class, make PPT in groups and give reports. Teachers make summary and students rethink. Hot current affairs are used to attract students' interest.

Comparative teaching method includes taxation scope of added-value tax and business tax and the difference between mixed sale behavior and sideline behavior. The above contents can be listed in the form of table, and students can clearly know mixed sale behavior aims at the same sale heavier and the price comes from the sane buyer, while sideline behavior is not always the case. For mixed sale behavior, only one kind of tax needs paying according to owners, while sideline behavior involves respective accounting problem.

4. To construct multi-dimension and diversified evaluation system

Test paper is also adopted to examine theoretical knowledge. Except final test paper, process assessment proportion should increase. For example, simulation of tax declaration and simulation of tax administration court can be adopted to cultivate students' practical ability. Final general score is composed of class attendance, question asking, assignment, process assessment and final examination.

5. To grasp two key links - construction of comprehensive tax revenue simulation training room and construction of off-campus training base

Comprehensive tax revenue simulation training room should be set up so that students can carry out role play, make real situations reappear and know well various businesses. Colleges should contact enterprises, firms and tax authorities as early as possible to establish stable and long-term cooperation, break the limit of internship in the senior year and arrange students to intern from the junior year in batches in order to help then be familiar with work practice as early $s$ possible.

6. To establish Tax Law website and form interactive teaching, watching and practice

Tax Law website provides a new communication platform for both students and teachers. Teachers can upload courseware, video and exercises to the website so that students can preview, practice and review in their spare time. Besides, students can communicate with teachers for knowledge points they cannot understand through real-time communication or leaving a message so as to further deepen teaching effects.

Tax Law teaching cannot adopt cramming method and exercise stuffing tactic. It is required to start with national requirements for quality and ability of accounting personnel to re-position the course, reform teaching materials, teaching method, learning methods as well as software and hardware conditions, further optimize teaching quality and make students learn and apply with interests and have the ability to show themselves. In this way, a successful way can be created for students.

\section{References}

[1] Ke Xiaoxia, Thoughts on Tax Law teaching reform for accounting major [M]. Journal of Liaoning Economic Management Cadre Institute, 2011.2:105-106

[2] Zhu Lirong, Thoughts on Tax Law teaching reform for accounting major [J] China Education Innovation Herald, 2011.11:155-155

[3] Wang Xiumin, Discussion on practical teaching of Tax Law for accounting major [J]. Cooperative Economy and Science, 2012.6:111-112

[4] Li Yu, Study on practical teaching of Tax Law based on cultivating applied talents [J]. Business Economy

[5] Ni Xiuying, Thoughts on Tax Law teaching reform based on applied talent training objective [J]. Journal of Xingtai University, 2011.3:50-51 